\title{
Fungi Influence in the Bio-removal of Chromium Ions from Chemical Laboratories
} Wastewater

\author{
Wessam M. Morsi ${ }^{1}$, Eglai A. Ghoniemy ${ }^{2}$, Tarek F. Mohammaden', El-Shahat M. \\ Ramadan $^{3}$, Mai M. Ikhawaga ${ }^{2}$ and Mohamed M. Rezk ${ }^{1}$ \\ ${ }^{1}$ Isotopes Department, Nuclear Materials Authority, Egypt. \\ ${ }^{2}$ Botany and Microbiology Department, Faculty of Science (Girls), Al-Azhar University, Egypt. \\ ${ }^{3}$ Faculty of Agriculture, Ain Shams University, Egypt.
} Received: 10 March 2020 / Accepted 30 April 2020 / Publication date: 20 May 2020

\begin{abstract}
Four fungal and one bacterial isolate were isolated from a liquid waste sample of Nuclear Material Authority laboratories. Those dried biomasses were screened for chromium (Cr) adsorption, where the most potent isolate was identified as Aspergillus niger. Using $\mathrm{Cr}$ synthetic solutions many factors (time, concentration, $\mathrm{pH}$ and temperature) were investigated for controlling the biosorption process. Aspergillus niger was examined by ESEM-EDX and the FTIR techniques before and after the sorption process, also the adsorption data were handled by different kinetics and isotherm models. The application on the real liquid waste revealed that the bio-uptake capacity was $52 \mathrm{mg} / \mathrm{g}$ for Cr.
\end{abstract}

Keywords: fungal, biosorption, liquid waste, chromium.

\section{Introduction}

Chromium (Cr) metal belongs to the transition elements (with an electronic configuration of $\mathrm{Ar}$ $3 \mathrm{~d}^{5} 4 \mathrm{~s}^{1}$ ), naturally found in rocks, soil, plants, animals and volcanic dust. In addition, several industrial activities yield the chromium in their resulted wastes (e.g. electroplating, fertilizers, pigments, tanning and mining) (Hlihor et al., 2017 and Oves et al., 2017). As a heavy toxic metal, Cr is nonbiodegradable so, accumulates in soil, water and living organisms causing toxic effect and diverse ecosystems even in relatively its low concentrations (Celik and Demirbas, 2005; Ahmad et al., 2006 and Abdullah, et al., 2019).

Among several Cr-ionic species, the $\mathrm{Cr}$ (III) and $\mathrm{Cr}$ (VI) are the most stable forms. $\mathrm{Cr}$ (III) is less mobile and less toxicity than $\mathrm{Cr}(\mathrm{VI})$ which is considered the most toxic form of $\mathrm{Cr}$ and usually occurs as chromate $\left(\mathrm{CrO}_{4}^{-2}\right)$ or dichromate $\left(\mathrm{Cr}_{2} \mathrm{O}_{7}^{-2}\right)$ oxyanions (Talaiekhozani and Rezania, 2017). $\mathrm{Cr}(\mathrm{VI})$ is commonly associated with cancer and hemorrhaging in the digestive tract (Faisal and Hasnain, 2004). Consequently, the discharging of wastes (solid and/or liquid) containing $\mathrm{Cr}$ to the environment without the proper treatment is one of the most serious environmental issues, taking in consideration that the safe limit of Cr-concentration in water is setting between 1-8 $\mathrm{mg} / \mathrm{L}$ based on the $\mathrm{Cr}$-ion species while its concentration in the industrial effluents usually ranges between 2 and $5 \mathrm{~g} / \mathrm{L}$ (Gokila et al., 2017).

Accordingly, removal of heavy toxic metals (like $\mathrm{Cr}$ ) from the wastewater was a matter of concern by many workers and researches in which various removal techniques were employed. Conventionally, the methods served for metal removal include chemical precipitation, ion-exchange, floatation, solvent extraction, membrane filtration and adsorption, etc. (Pehlivan and Altun, 2008; Donia et al., 2009; Wang et al., 2017). Unfortunately, most of these methods become less effective and costly more when they used with the liquid waste of large volume and low metal concentrations, in addition, they usually left contaminated solid wastes to need for further treatment. However, the bio-removal for heavy and toxic metals from the wastewater appeared as a promising alternative and gained important credibility due to its eco-friendly nature, high performance and the cost-effectiveness so, varieties of biomaterials such as bacteria, yeast algae and fungi have been successfully used as biosorbents for heavy metals removal (Volesky, 1994; Kapoor and Viraraghavan, 1995; Tunali et al., 2006; Pehlivan and Altun, 2008; Alluri, et al., 2007; Iyer et al., 2005).

Corresponding Author: Mohamed M. Rezk, Isotopes Department, Nuclear Materials Authority, Egypt. E-mail:ddRezk@yahoo.com 
Although the living biomasses acted in satisfaction behavior as bio-removal and bio-sorbent for heavy metals but more recent studies have been demonstrated that the dead biomass behaved more effective in removing heavy metals than live biomass (Doshi et al., 2007; Mane et al., 2011; Munoz et al., 2012). The reasons for this approach are: the living biomass requires a continuous supply of nutrients and the microorganism's validity could be negatively affected by the metal toxicity while dead biomass can avoid these obstacles and the used cells can be easily regenerated.

The current work was proposed and designed to handle the chromium pollutant in the effluent resulted from the laboratory activities in the Nuclear Materials Authority (NMA), Egypt. The dried fungal biomass is the used removal material where it was testing under several working conditions to optimize the most suitable ones yielding the best metal-removal efficiency. By this work, a scientific and effective contribution to environmental protection had been conducted.

\section{Materials and Methods}

\section{The bio-sorbent preparation}

Different microorganisms were sourced from the interested effluent where few drops were put onto the appropriate medium for developing the fungi as well as the bacteria.

\section{Fungal media}

Czapek-Dox agar was the used medium for the growing and isolation of the fungi. It composed of $\mathrm{NaNO}_{3}(2 \mathrm{~g} / \mathrm{L}), \quad \mathrm{KH}_{2} \mathrm{PO}_{4}(1 \mathrm{~g} / \mathrm{L}) ; \quad \mathrm{MgSO}_{4} .7 \mathrm{H}_{2} \mathrm{O}(0.5 \mathrm{~g} / \mathrm{L}), \mathrm{KCl}(0.5 \mathrm{~g} / \mathrm{L}), \mathrm{FeSO}_{4} .5 \mathrm{H}_{2} \mathrm{O}$ (traces),sucrose $(30 \mathrm{~g} / \mathrm{L})$ and agar $(15 \mathrm{~g} / \mathrm{L})$ with adjusted $\mathrm{pH}$ at values ranged between 4 and 5 .

\section{Bacterial media}

The used media was mainly made up of (g/l): nutrient agar medium beef extract (3), peptone (10), Agar (20) and up to $1000 \mathrm{ml}$ using distilled water. The $\mathrm{pH}$ of the medium was adjusted at $\mathrm{pH} 6.0$ before sterilization.

\section{Isolation and purification}

\section{Spray method}

Using the spatula spray technique (Porter et al., 1960), the sample was spreading on Dox agar plates, nutrient agar and starch agar media respectively, then the plates were incubated for 7 days at $30^{\circ} \mathrm{C}$. Consequently, colonies of fungi and bacteria were isolated then purified by streaking several times on Dox agar, nutrient agar and starch-nitrate agar medium respectively till obtaining pure cultures which re-cultured on slants of the same medium.

\section{Testing of the biomass adsorption efficiency}

The hyphal tips were removed and plated on the surface of Dox agar plates conducted pure microorganisms were dried at $70{ }^{\circ} \mathrm{C}$ for about $3 \mathrm{hrs}$. Dried biomasses were powdered then tested for $\mathrm{Cr}$ adsorption under the following fixed conditions; $0.5 \mathrm{~g}$ of each dried biomass, $\mathrm{Cr}$ solution of 100 $\mathrm{mg} / \mathrm{L}, \mathrm{pH} 4.5$ (simulated to the media $\mathrm{pH}$ ), contact time 30 minutes and at room temperature.

\section{Biomass identification}

\section{Isolation and purification of metal tolerant microorganisms}

An appropriate amount of liquid waste (waste sample containing uranium and thorium ions) was poured into the Czapek-Dox agar medium and incubated at $25 \pm 2^{\circ} \mathrm{C}$ for 7 days. The emerging fungi were purified until single uniform colonies were obtained and transferred into Dox agar slants and preserved.

\section{Microbial adsorption capacities}

The microbial isolates inoculated into the Czapek-Dox broth medium and incubated for 7 days at $35 \pm 2{ }^{\circ} \mathrm{C}$. The mycelial biomass was harvested and dried at $70^{\circ} \mathrm{C}$ in the dryness oven. The dried biomass was tested for their $\mathrm{U}$ and $\mathrm{Th}$ adsorption capacities under the following fixed conditions; 0.5 
$\mathrm{g}$ of each dried biomass, $\mathrm{U}$ and Th solution of $100 \mathrm{mg} / \mathrm{L}, \mathrm{pH} 4.5$ (similar to the media $\mathrm{pH}$ ), contact time 30 minutes at room temperature. The most potent microorganism was identified.

\section{Identification of the selected fungus}

The heaviest metal tolerant isolate was identified on the basis of macroscopic (colonial morphology, color, texture, shape, diameter and appearance of colony) and microscopic characters (septation in mycelium, presence of specific reproductive structures, shape and structure of conidia) according to Domsch et al. (1980), Barnett and Hunter (1999) and Zafar et al. (2006). The identification was confirmed through the $18 \mathrm{~S}$ rRNA gene sequencing and phylogenetic analysis. The fungus was transferred to Czapek Dox media and incubated with shaking $\left(180 \mathrm{rev} \mathrm{min}^{-1}\right)$ at $25 \pm 2{ }^{\circ} \mathrm{C}$ for 7 days. Mycelia were collected by centrifugation and DNA was extracted. Purified DNA was subjected to PCR amplification using primers ITS1 and ITS4. Fungal identification methods were based on their internal transcribed spacer ribosomal DNA (ITS-rDNA) sequences. A pair of primers ITS1 (5'-TCC GTA GGT GAA CCT GCG G-3') and ITS4 (5'-TCC TCC GCT TAT TGA TAT GC$3^{\prime}$ ) was used for ITS-rDNA amplification (White et al., 1990), which produces an amplicon of approximately $550 \mathrm{bp}$ of the ITS region. Sequence data was analyzed in the Gene Bank database by using the BLAST program available on the National Center for Biotechnology Information website (www.ncbi.nlm.nih.gov). The unknown sequence was compared to all of the sequences in the database to assess the DNA similarities (Altschul et al., 1997). Alignment and molecular phylogeny were evaluated using Bio Edit software. Purification and sequencing of PCR products for the isolate under study were performed in the Sigma Company of scientific service.

\section{Effluent characterization and $\mathrm{Cr}$ (VI) determination}

Without further addition of any chemical reagents or components, the liquid waste was quantitatively analyzed to identify its components and their concentrations using the inductively coupled plasma- emission spectroscopy (ICP-ES) which hold in the Nuclear Materials Authority. On the other hand, estimating of the $\mathrm{Cr}$ concentrations all over the work steps was carried out spectrophotometrically using 1,5 -Di-phenyl carbazide at $540 \mathrm{~nm}$ wavelength.

\section{Factors controlling the biosorption process}

It is worth to mention that all the batch experiments, mentioned hereinafter, were executed using $\mathrm{Cr}$ synthetic solution of $100 \mathrm{mg} / \mathrm{L}$ concentration. Firstly, a synthetic solution of $1000 \mathrm{mg} / \mathrm{L} \mathrm{Cr}$ was prepared by dissolving $0.2828 \mathrm{~g}$ of potassium dichromate $\mathrm{K}_{2} \mathrm{Cr}_{2} \mathrm{O}_{7}$ (AR Grade - Merck Co.) in $1 \mathrm{~L}$ de-ionized water, then a series of $100 \mathrm{mg} / \mathrm{L} \mathrm{Cr}$-solutions was prepared by the adequate dilution using further de-ionized water.

Also, in each experiment the dried biomass was added to the $\mathrm{Cr}$ synthetic solution in the Erlenmeyer flasks of $250 \mathrm{ml}$ volume under the designed experimental conditions then the flasks were inoculated and shacked at $200 \mathrm{rpm}$ by the rotary shaker. After the planned shacking time, the mixtures were filtered by Whatman filter paper and $\mathrm{Cr}$ concentration was chemically estimated in the filtrates. The removal percentage of $\mathrm{Cr}$ ions and the uptake capacity of the dried biomass $\left(\mathrm{q}_{\mathrm{e}}\right)$ were calculated according to the following equations (Abu El-Soad et al., 2019; Abd El-Magied et al., 2018a):

$$
\begin{gathered}
\text { Removal percentage }(\%)=\left[\left(\mathrm{C}_{\mathrm{i}}-\mathrm{C}_{\mathrm{e}}\right) / \mathrm{C}_{\mathrm{i}}\right] \times 100 \\
\mathrm{q}_{\mathrm{e}}=\left(\mathrm{C}_{\mathrm{i}}-\mathrm{C}_{\mathrm{e}}\right) \mathrm{X}(\mathrm{V} / \mathrm{m})
\end{gathered}
$$

where $\mathrm{C}_{\mathrm{i}}$ is the initial $\mathrm{Cr}$ ions concentration $(\mathrm{mg} / \mathrm{L}), \mathrm{C}_{\mathrm{e}}$ is the $\mathrm{Cr}$ concentration remained in the filtrate $(\mathrm{mg} / \mathrm{L}), \mathrm{m}$ is the dried biosorbent mass $(\mathrm{g})$ and $\mathrm{V}$ equals the volume of used solution $(\mathrm{L})$.

\section{Effect of pH}

The role played by various solution-pH values was examined by applying different $\mathrm{pH}$ values in the range from 1 to 9 . Adjusting the $\mathrm{pH}$ at the required value was conducted using $\mathrm{HCl}(1 \mathrm{M})$ and/or $\mathrm{NaOH}(1 \mathrm{M})$ while the other experimental conditions were kept constant as contact time (30 min.), $\mathrm{Cr}$ initial concentration $(100 \mathrm{mg} / \mathrm{L})$, dried biomass weight $(0.5 \mathrm{~g})$ and at the room temperature. 


\section{Effect of contact time}

Investigation of contact time effect was verified using time values from 5 to 60 minutes. Except for the $\mathrm{pH}$ value 4 , the optimum conducted value, the other conditions were applied similar to those in the above experiment.

\section{Effect of $\mathrm{Cr}$ initial concentration}

Under constant conditions of $\mathrm{pH} \mathrm{4,30} \mathrm{min} \mathrm{contact} \mathrm{time,} 0.5 \mathrm{~g}$ dried biomass and room temperature, the effect of $\mathrm{Cr}$ initial concentration was tested using different concentrations ranged between 50 and $400 \mathrm{mg} / \mathrm{L}$.

\section{Effect of biomass dosage}

At $\mathrm{pH}$ 4, 30 min contact time, 300ppm Cr concentration and room temperature, various dried biomass dosages $(0.1-1.5 \mathrm{~g} / 100 \mathrm{ml}$ solution) were applied to study the effect of the biomass dosage on the Cr-adsorption process.

\section{Effect of Temperature}

The temperature influencing on the biosorption process was tested by applying temperatures degrees varied from $\left(30\right.$ to $\left.100^{\circ} \mathrm{c}\right)$ under the other conducting optimum conditions ( $\mathrm{pH} 4,30 \mathrm{~min}$. contact time, $300 \mathrm{mg} / \mathrm{L} \mathrm{Cr}$ concentration and $0.2 \mathrm{~g}$ dried biomass dosage).

\section{Kinetics and isotherms of the biosorption process}

Cr-ions removal by the biosorbent and the heterogeneity of the biosorbent surface can be formulated thorough testing of the experimental data by several kinetic models consequently. The most famous kinetic models are the Pseudo-first and pseudo-second-order kinetics models which are expressed by the following equations (Glasston et al., 1941; Abd El-Magied et al., 2018b):

$$
\begin{gathered}
\text { Pseudo - first order: } \log \left(\mathrm{q}_{\mathrm{e}}-\mathrm{q}_{\mathrm{t}}\right)=\log \left(\mathrm{q}_{1 \mathrm{st}}\right)-\frac{\mathrm{k}_{1}}{2.303} \mathrm{t} \\
\text { Pseudo - second order: } \frac{\mathrm{t}}{\mathrm{q}_{\mathrm{t}}}=\frac{1}{\mathrm{k}_{2} \mathrm{q}_{2 \mathrm{nd}}^{2}}+\frac{1}{\mathrm{q}_{2 \mathrm{nd}}} \mathrm{t}
\end{gathered}
$$

Where $\mathrm{q}_{\mathrm{t}}$, is the experimental adsorption capacity at time $(\mathrm{t}), \mathrm{q}_{1 \mathrm{st}}$ and $\mathrm{q}_{2 \mathrm{nd}}$ are the calculated adsorption capacity from the pseudo-first and the pseudo-second-order models $(\mathrm{mg} / \mathrm{g})$ respectively, $\mathrm{k}_{1}\left(\mathrm{~min}^{-1}\right)$ and $\mathrm{k}_{2}$ (g/mg.min) are the rates constant of pseudo-first and pseudo-second-order models respectively.

On the other hand, the adsorption isotherms were carried out using different $\mathrm{Cr}$ initial concentrations at temperature of $25 \pm 2{ }^{\circ} \mathrm{C}$ and the obtained experimental data were tested with the linearized form of Langmuir isotherm which describes the solid phase adsorption system and Frendlich isotherm which gives indication for multilayer adsorption on a heterogeneous adsorbent surface isotherm models (Freundlic, 1906; Langmuir, 1918).

The linear form of Langmuir adsorption isotherm is expressed by the equation (Sadeek et al., 2014; Abd El-Magied et al., 2017a):

$$
\frac{\mathrm{C}_{\mathrm{e}}}{\mathrm{q}_{\mathrm{e}}}=\frac{\mathrm{C}_{\mathrm{e}}}{\mathrm{q}_{\mathrm{L}}}+\frac{1}{\mathrm{~K}_{\mathrm{L}} \mathrm{q}_{\mathrm{L}}}
$$

where $\mathrm{q}_{\mathrm{L}}$ is the Langmuir maximum adsorption capacity $(\mathrm{mg} / \mathrm{g})$ and $\mathrm{K}_{\mathrm{L}}$ is the Langmuir binding constant. 2017b).

The linear form of Freundlich model is as follow (Sadeek et al., 2014; Abd El-Magied et al.,

$$
\log \mathrm{q}_{\mathrm{e}}=\log \mathrm{K}_{\mathrm{f}}+\frac{1}{\mathrm{n}} \log \mathrm{C}_{\mathrm{e}}
$$

where $K_{F}$ and $1 / n$ are constants related to theoretical adsorption capacity and intensity of adsorbent/adsorbate binding respectively. 


\section{Verification of Cr-sorption onto the dried biomass}

Changes of the biomass surface and its functional groups due to $\mathrm{Cr}$ adsorption were verified by exposing the dried biomass (before and after adsorption process) for investigation using the environmental scanning electron microscope-energy dispersive X-ray (ESEM-EDX) and the Fourier transform infrared spectroscopy (FTIR). The ESEM-EDX is a Philips type model XL30 while the FTIR is a thermo-scientific type works in the range of 400 to $4000 \mathrm{~cm}^{-1}$; model NICOLET-iS10, USA and both of the instruments are hold in the NMA. For the FTIR investigation, the unloaded and loaded dried biomasses were initially blended with the potassium bromide $(\mathrm{KBr})$ before subjecting to the FTIR analysis.

\section{Desorption of loaded metal}

Elution of the adsorbed $\mathrm{Cr}$ from the bio-adsorbent was executed using various eluting solutions of $1 \mathrm{M}$ concentration and represented in; $\mathrm{HCl}, \mathrm{H}_{2} \mathrm{SO}_{4}, \mathrm{Na}_{2} \mathrm{CO}_{3}$ and $\mathrm{NaCl}$. The elution process was carried out by adding $0.2 \mathrm{~g}$ of the loaded biomass to $100 \mathrm{ml}$ of the eluting solution into an Erlenmeyer flask then shacked for 30 minutes at room temperature. The highest efficient desorbing solution was retested at different molarities $(0.5,1,1.5,2$ and 2.5).

\section{Biomass reusability}

Reusability of the bio-adsorbent was examined through successive adsorption/desorption cycles using the efficient concentration of the desorbing solution and the biomass adsorption capacity was calculated at the end of each cycle.

\section{Application}

\section{Treatment of real liquid waste}

The achieved optimum adsorption conditions of $\mathrm{Cr}(\mathrm{pH}$, contact time, Cr-initial concentration, biomass dosage and working temperature) were applied together with $100 \mathrm{ml}$ of the target lab effluent and after filtration, the filtrate was analyzed using the ICP-ES and compared to the chemical analysis data of the pre-treated effluent.

\section{Metal recovery and the environmental aspect}

To recover the adsorbed $\mathrm{Cr}$ ions in the form of solid material and to avoid the creation of solid waste (the loaded biomass), the loaded biomass was burned at $850{ }^{\circ} \mathrm{C}$ for 2 hours in the muffle furnace and after cooling the residue was directly identified by the ESEM-EDX

\section{Results and Discussion}

\section{Adsorption capacities of microbial isolates}

The microbial isolates were categorized into four fungal types assigned as F1, F2, F3 and F4 in addition to one bacterial species (fig.1). The dried biomasses of the purified microbial isolates were examined for their $\mathrm{Cr}$ adsorption efficiency. As shown in table (1) the dried biomass of fungal isolate (F4) gave the highest adsorption percentage. So, this fungus was selected as the most potent biosorption and be used for further studies.

Table 1: The adsorption efficiency percentage of microbial isolates dried biomass

\begin{tabular}{cc}
\hline Dried biomass of MicrobialIsolates & Adsorption Efficiency (\%) \\
& Cr \\
\hline F1 & 45 \\
F2 & 38 \\
F4 & 52 \\
Bacteria & 64 \\
\hline
\end{tabular}



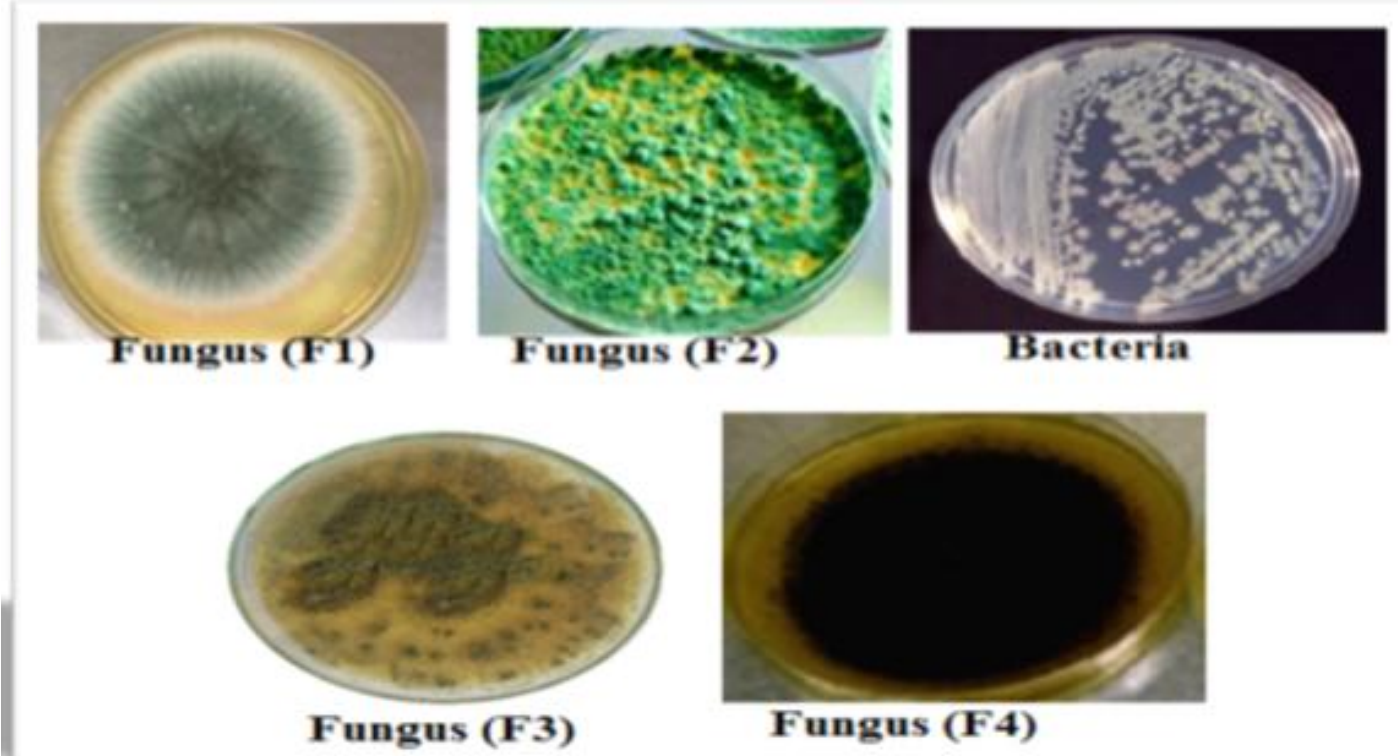

Fungus (F4)

Fig. 1: The microbial isolates

\section{Identification of the selected fungus}

Micro-morphological studies of fungal isolate, F4 using a light microscope revealed that the fungal isolate grew rapidly on the Czapek Dox medium at $28 \pm 2^{\circ} \mathrm{C}$, reaching a size of $5-7 \mathrm{~cm}$ in 5-7 days. The mycelium surface was velvety and smooth with regular radial ornamentation. The spores had ahead of carbon black color and without any transudate. The reverse of the fungus appeared colorless then yellow to yellow-brownish. The vesicle was globose or subglobose with a diameter of $28 \mu \mathrm{m}$. The conidiophore was globular with a diameter of $9.5 \mu \mathrm{m}$. The size of Uniseriate Sterigmata was in the range of $(7.7 \times 4.5 \mu \mathrm{m})$. The spores are subglobose with a diameter of $3.5 \mu \mathrm{m}$. To confirm the identification of fungal isolate, the 18S rRNA gene sequencing and phylogenetic analysis were used. The 18S rRNA gene sequencing was compared with the sequence of Aspergillus sp. through multiple sequence alignment. Experimental analysis of PCR amplification was studied through agarose gel electrophoresis. Figure (2) shows the phylogenetic tree of the fungal isolate, which showed that the isolate was closed to Aspergillus nigerstrain MK457457.1 by $100 \%$ identity.

\section{Factors controlling the biosorption process}

\section{Effect of $\mathbf{p H}$}

For biosorption of heavy metal ions, $\mathrm{pH}$ is one of the most important environmental factors. The $\mathrm{pH}$ value of solution strongly influences not only the site dissociation of the biomass' surface but also the solution chemistry of the heavy metals: hydrolysis, complexation by organic and/or inorganic ligands, redox reactions, precipitation, the speciation and the biosorption availability of the heavy metals (Esposito et al., 2002 and Wang, 2002).

The effect of $\mathrm{pH}$ on $\mathrm{Cr}$ (III) biosorption by A. niger showed a marked $\mathrm{pH}$ dependence (Fig.3). The $\mathrm{Cr}$ (III) uptake increased significantly as the $\mathrm{pH}$ increased from 2 to 4 where the maximum uptake of $\mathrm{Cr}$ (III) was noted at $\mathrm{pH} 4(52 \mathrm{mg} / \mathrm{g}$ ). The low $\mathrm{Cr}$ (III) biosorption at $\mathrm{pH} 2$ is reasonably ascribed to that the cell wall ligandswere closely associated with the hydronium ions $\left[\mathrm{H}_{3} \mathrm{O}\right]^{+}$and restricted the approachof metal cations as a result of the repulsive force. Additionally, the competence between protons and $\mathrm{Cr}$ (III) on occupying the binding sites results in lowering the biosorption of the metal ions (Kratochvil et al., 1998; Yun et al., 2001).

On the other hand, decreasing the protonation of the biosorbent-surface with increasing of the $\mathrm{pH}$ from 2 to 4 lowers the electrostatic repulsion between the surface and metal ions (Reddad et al., 2002) hence increases the metal ions uptake by the binding sites. A declining sorption trend was observed with the $\mathrm{pH}$ values greater than 4 which are likely explained by decreasing of $\mathrm{Cr}$ (III) solubility at the high $\mathrm{pH}$ values hence, its precipitation from the solution (Yun et al., 2001). 


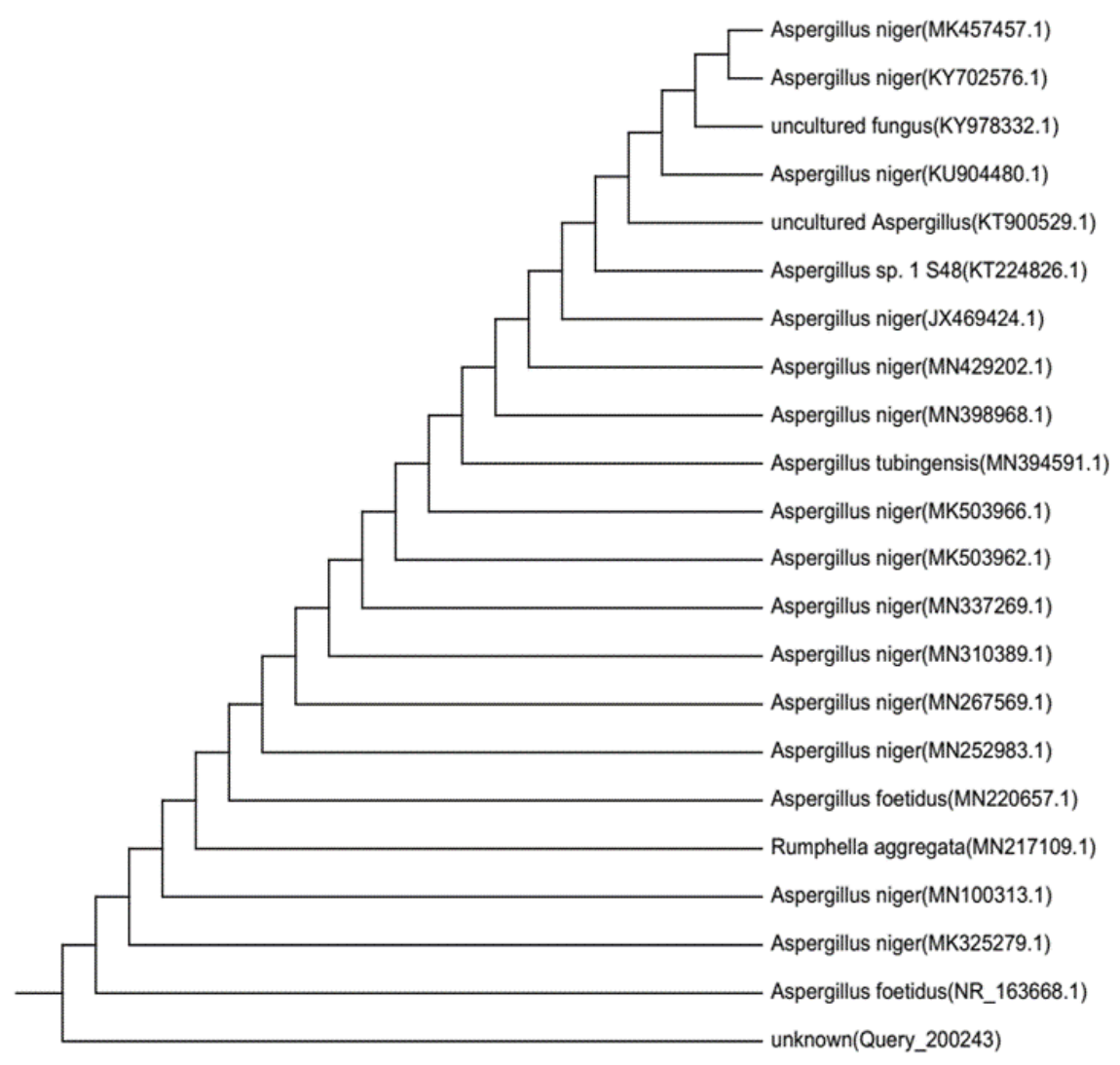

Fig. 2: The phylogenetic tree of the Aspergillus nigerstrain MK457457.1

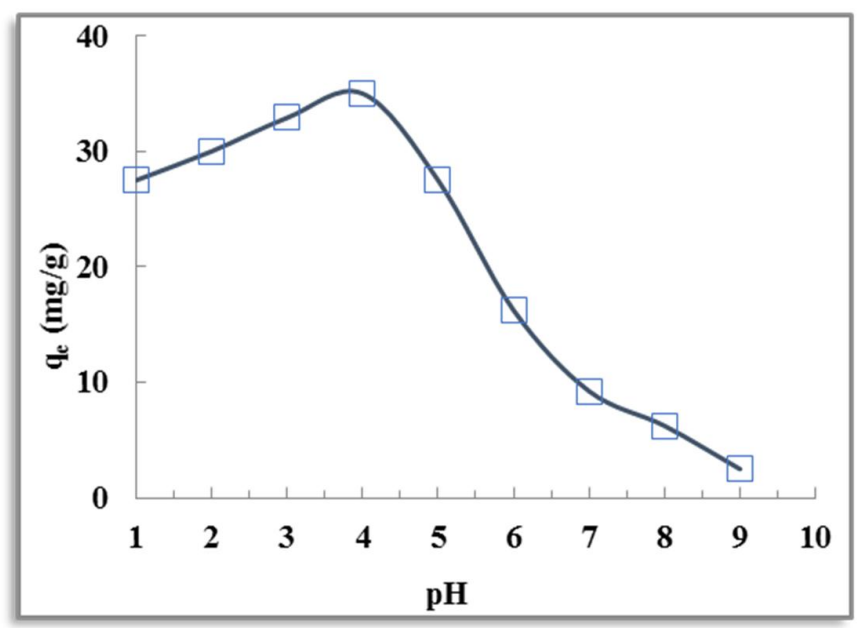

Fig. 3: Effect of different $\mathrm{pH}$ values on $\mathrm{Cr}$ adsorption processes onto A. niger dried biomass.

\section{2-Effect of contact time on $\mathrm{Cr}$ (III) biosorption}

Testing the contact time effect on the biosorption of Cr(III) by A. niger (Fig.4) showed that the 30 minutes was the optimum contact time to conduct the maximum $\mathrm{Cr}$ (III) uptake $(52 \mathrm{mg} / \mathrm{g})$. The availability of bio-sorbent active sites appears the main player in the metal uptake. Initially, the wide availability of active sites accompanied with the rapid increase in the adsorption till reaching the optimum contact time (30 min.), and then as time passes the metal uptake by the sorbent surface goes down as the competition for decreasing the availability of active sites intensifies by the metal ions remaining in the solution. The binding mechanisms of heavy metals by biosorption could be explained 
by the physical and chemical interactions between cell wall ligands and adsorbates by ion exchange, complexation, coordination and microprecipitation. The diffusion of the metal from the bulk solution to active sites of biosorbents occurs predominantly by passive transport mechanisms (Veglio and Beolchini, 1997, Ferraz et al., 2004; Malik, 2004) and various functional groups such as carboxyl, hydroxyl, amino and phosphate existing on the cell wall of biosorbents can bind the heavy metals (Wang and Chen 2006).

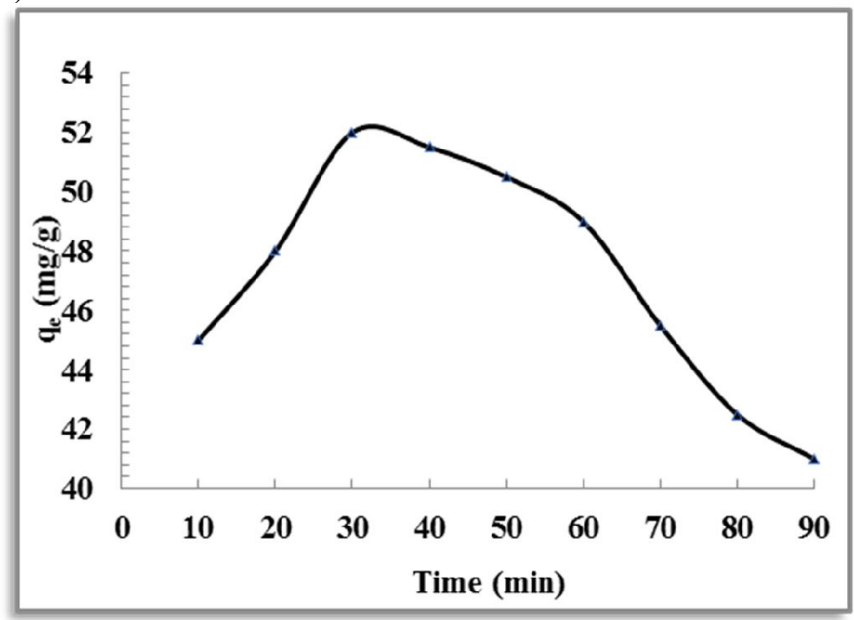

Fig. 4: Effect of different contact times on $\mathrm{Cr}$ adsorption process onto A. niger dried biomass.

\section{Adsorption kinetics}

The fast biosorption kinetics observed initially is typical for the biosorption process involving no energy mediated reactions and metal removal from solution are due to purely physicochemical interactions between biomass and metal solution (Yi and Lian, 2012; Lee et al., 2015). Kinetic models test the experimental data as a function for heterogeneity of the adsorbent surface and the metal removal rate in order to design appropriate sorption processes. The sorption kinetic models used in this study include pseudo-first-order and pseudo-second-order.

The obtained $\mathrm{q}_{\mathrm{e}}, \mathrm{q}_{\mathrm{cal}}$ and $\mathrm{R}^{2}$ values of $\mathrm{Cr}$ point to that adsorption of metal onto the A. niger follow the pseudo-second-order rather than pseudo-first-order that suggests the adsorption rate depends on the properties of both adsorbate and adsorbent (Table 2 and Figs $5 \& 6$ ).

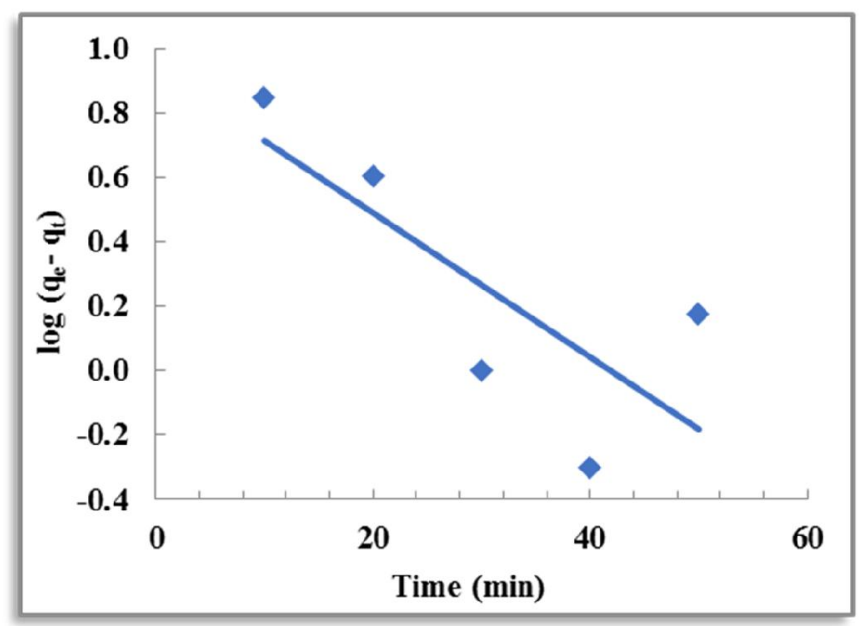

Fig. 5: Pseudo first-order model for $\mathrm{Cr}$ adsorption onto A. nigerdried biomass. 


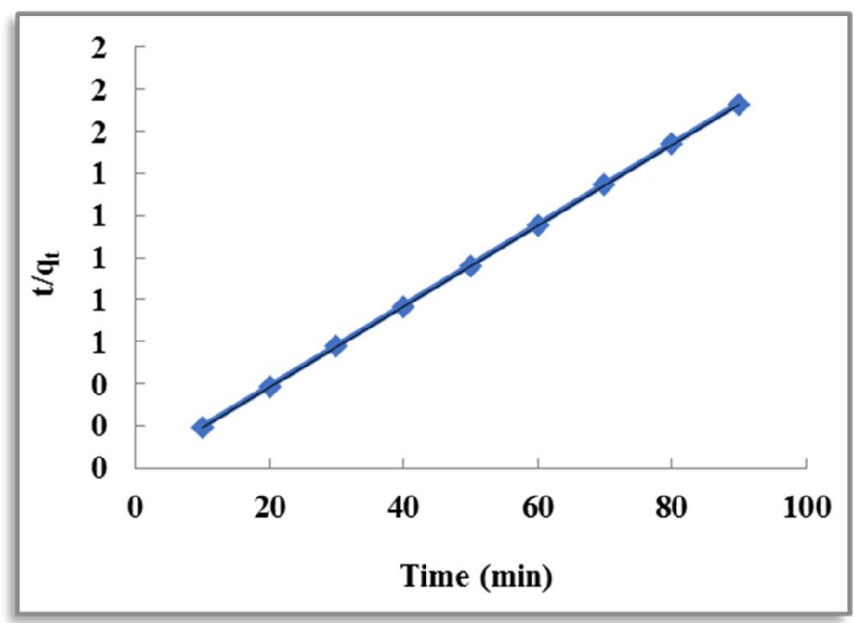

Fig. 6: Pseudo Second-order model for Cr adsorption onto $A$. niger dried biomass.

Table 2: Kinetic data for the adsorption of $\mathrm{Cr}$ ions onto A. niger dried biomass

\begin{tabular}{lll}
\hline Kinetic model & Parameters & $\mathbf{C r}$ \\
\hline Experimental & $\mathbf{q}_{\mathbf{e}}(\mathbf{m g} / \mathbf{g})$ & 52 \\
& $\mathbf{q}_{1 \mathbf{s t}}(\mathbf{m g} / \mathbf{g})$ & 8.65 \\
Pseudo first order & $\mathbf{k}_{\mathbf{1}}\left(\mathbf{m i n} \mathbf{n}^{-1}\right)$ & 0.052 \\
& $\mathbf{R}^{\mathbf{2}}$ & 0.592 \\
& $\mathbf{q}_{2 \text { nd }}(\mathbf{m g} / \mathbf{g})$ & 52.0833 \\
Pseudo second order & $\mathbf{K}_{\mathbf{2}}(\mathbf{g} / \mathbf{m g} \cdot \mathbf{m i n})$ & $7.4 \mathrm{E}+11$ \\
& $\mathbf{R}^{\mathbf{2}}$ & 0.999 \\
\hline
\end{tabular}

\section{3-Effect of Initial Metal Ion Concentration}

Effect of initial metal ion concentration using dead Aspergillus nigerwas studied and results were shown in Fig (7) the maximum biosorption capacity of chromium was $52 \mathrm{mg} / \mathrm{g}$ with initial metal ion concentration of $300 \mathrm{mg} / \mathrm{L}$ for Aspergillus nigea. The percentage removal decreased as the concentration increased and it is due to lack of active sites $\mathrm{Cr}$ (III) uptake was noted to increase with the increase in metal ion concentration in the solution until it reached the maximum capacity of 52 $\mathrm{mg} / \mathrm{g}$ biosorbent

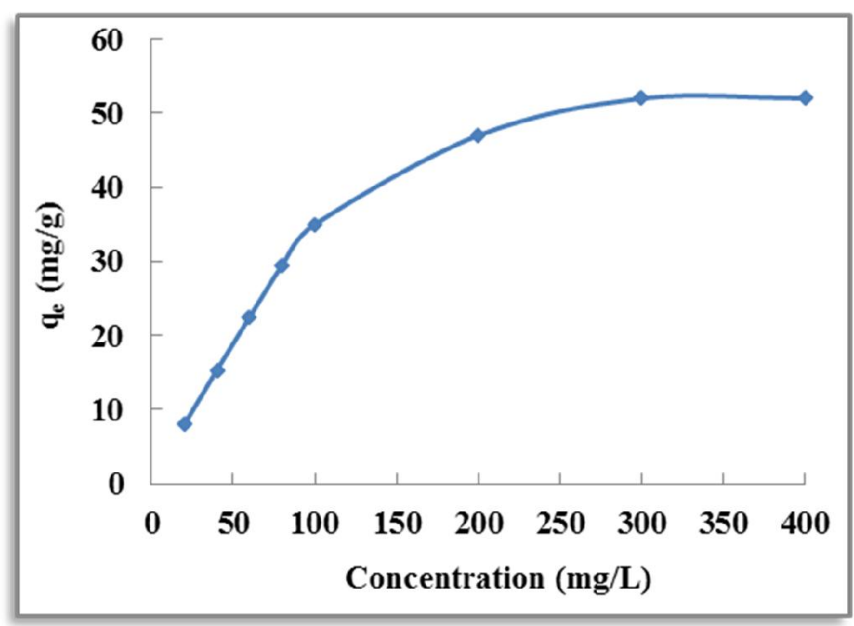

Fig. 7: Effect of $\mathrm{Cr}$ initial concentrations on adsorption process onto A. niger dried biomass.

\section{Adsorption isotherms}

Adsorption isotherms were carried out with different initial concentrations of $\mathrm{Cr}$ ion varying from 10 to $100 \mathrm{mg} / \mathrm{L}$. The obtained experimental data were tested with the linearized form of 
Langmuir (used to describe the solid phase adsorption systems) and Freundlich (indicator for multilayer adsorption on a heterogeneous adsorbent surface) isotherms models.

The adsorption isotherms of $\mathrm{Cr}$ obtained at $25^{\circ} \mathrm{C}$ were plotted according to Langmuir and Freundlich models (Fig. $8 \& 9$ respectively) while the estimated and calculated parameters were illustrated in the table (3).

Comparing the experimental adsorption capacities " $\mathrm{q}_{\mathrm{e}}$ " of $\mathrm{Cr}$ with the " $\mathrm{q}_{\mathrm{L}}$ " and " $\mathrm{K}_{\mathrm{F}}$ " from Langmuir and Freundlich models respectively as well as the regression coefficient " $\mathrm{R}^{2}$ " values obtained from both models, it can be concluded that the adsorption process of $\mathrm{Cr}$ by the A. niger dried biomass follows the Langmuir isotherm model. Also, the preferential distribution of Cron the solid biomass surface rather than in the liquid sorbate phase is highly suggested (Sar and D'Souza, 2002) and means that the adsorption process is controlled by the monolayer coverage system.

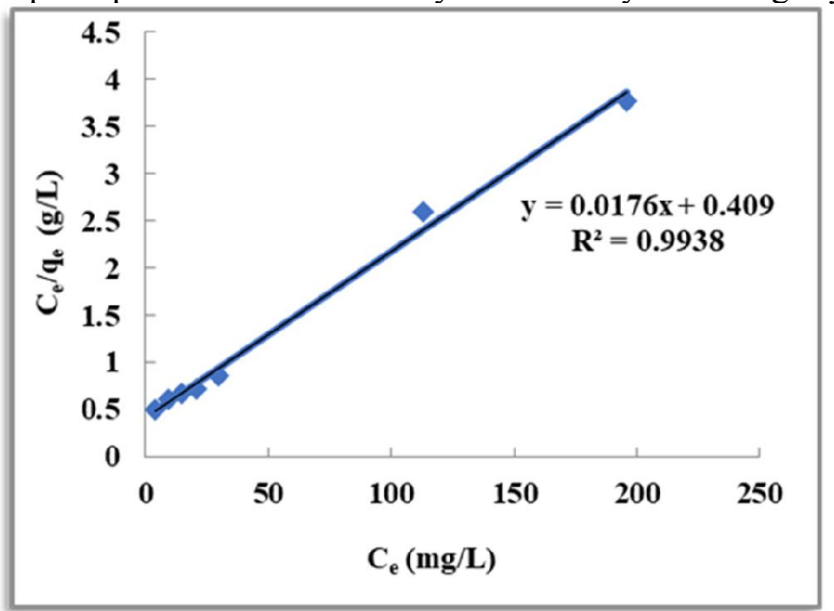

Fig. 8: Langmuir isotherm models for the Cr adsorption onto A. niger dried biomass.

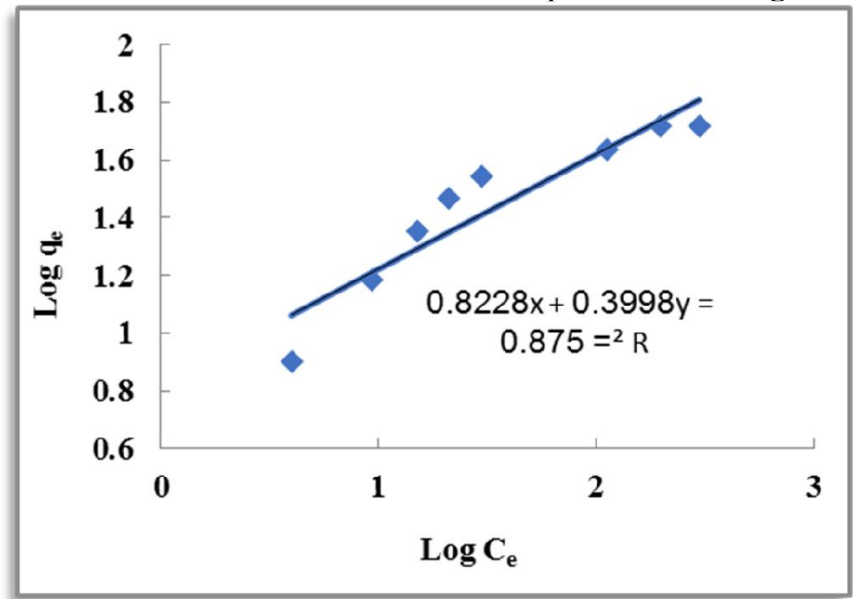

Fig. 9: Freundlich isotherm models for the $\mathrm{Cr}$ adsorption onto A.niger dried biomass.

Table 3: Data estimated from the adsorption isotherms of Cr biosorption process onto $A$. niger dried biomass.

\begin{tabular}{lclc}
\hline Isotherms model & Parameters & $\mathbf{C r}$ & Temp. \\
\hline Experimental & $\mathbf{q}_{\mathbf{e}}(\mathbf{m g} / \mathbf{g})$ & 52 & \\
& $\mathbf{q}_{\mathbf{L}}(\mathbf{m g} / \mathbf{g})$ & 56.818 & \multirow{2}{*}{$298 \mathrm{~K}$} \\
Langmuir & $\mathbf{K}_{\mathbf{L}}(\mathbf{L} / \mathbf{m g})$ & 0.043 & \\
& $\mathbf{R}^{2}$ & 0.994 & \\
& $\mathbf{K}_{\mathbf{F}}(\mathbf{m g} / \mathbf{g})$ & 6.649 & \multirow{2}{*}{$298 \mathrm{~K}$} \\
\hline \multirow{2}{*}{ Freundlich } & $\mathbf{N}$ & 2.501 & \\
& $\mathbf{R}^{2}$ & 0.875 & \\
\hline
\end{tabular}




\section{Effect of sorbent dose}

The concentration of biosorbent is also one of the significant factors to be considered for effective biosorption. Biosorption of chromium with varying biosorbent dosage is shown in Fig. (10) From the figure it has been observed that there is a decrease in qe with increase in sorbent dosage the ion uptake capacity at equilibrium (qe) decreased from $52 \mathrm{mg} / \mathrm{g}$ to $16.56 \mathrm{mg} / \mathrm{g}$ as the sorbent dose increased from $0.2 \mathrm{~g} / \mathrm{L}$ to $1.5 \mathrm{~g} / \mathrm{L}$ for $\mathrm{Cr}$. This may be a due increase in the binding sites in the biomass.

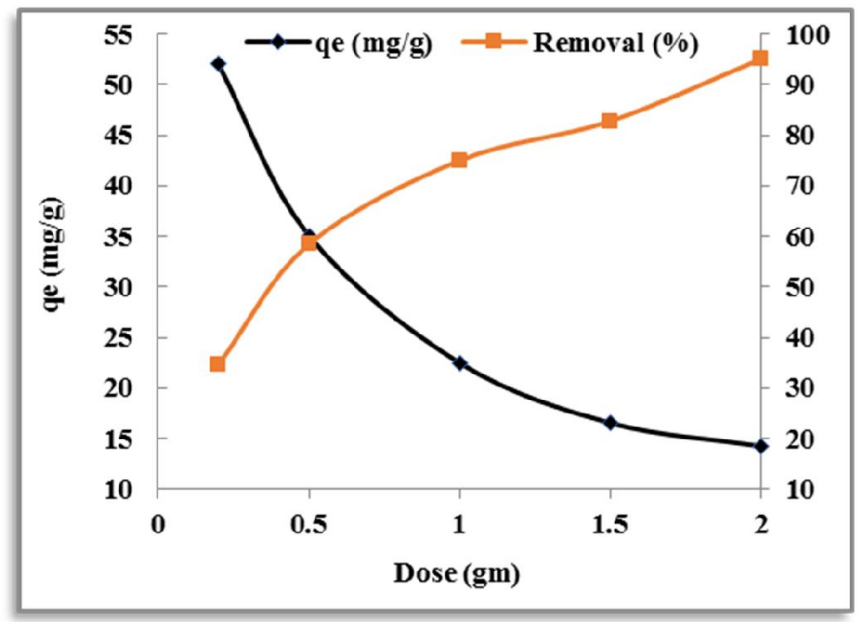

Fig. 10: Effect of $A$. niger dried biomass dosage on the biosorption processes of Cr.

\section{Effect of temperature}

The temperature has also an influence on the biosorption of metal ions, but to a limited extent under a certain range of temperature (fig. 11), which indicates that the ion-exchange mechanism exists in biosorption to some extent. The biosorption process is usually not operated at high temperature because it will increase the operational cost (Wang, 2002). Brady and Duncan (1994) found that temperature $\left(5-40{ }^{\circ} \mathrm{C}\right)$ had a minor effect on the accumulation level of $\mathrm{Cu}^{2+}, \mathrm{Co}^{2+}$ or $\mathrm{Cd}^{2+}$ by free cells of $\mathrm{S}$. cerevisiae in suspension. Adsorption reactions are normally exothermic, so biosorption capacity increases with a decrease of temperature (Kapoor and Viraraghavan, 1995). In the range of $15-40{ }^{\circ} \mathrm{C}$, the maximum equilibrium biosorption capacity for $\mathrm{Pb}$ (II), $\mathrm{Ni}$ (II) and $\mathrm{Cr}$ (VI) ions by the inactive $\mathrm{S}$. cerevisiae was reached at the temperature of $25^{\circ} \mathrm{C}$. The decrease in capacity at a higher temperature between 25 and $40{ }^{\circ} \mathrm{C}$ revealed that the processes of biosorption for these metal ions by S. cerevisiae are exothermic. The decrease of biosorption capacity at a higher temperature may be due to the damage of active binding sites in the biomass (Özer andÖzer, 2003).

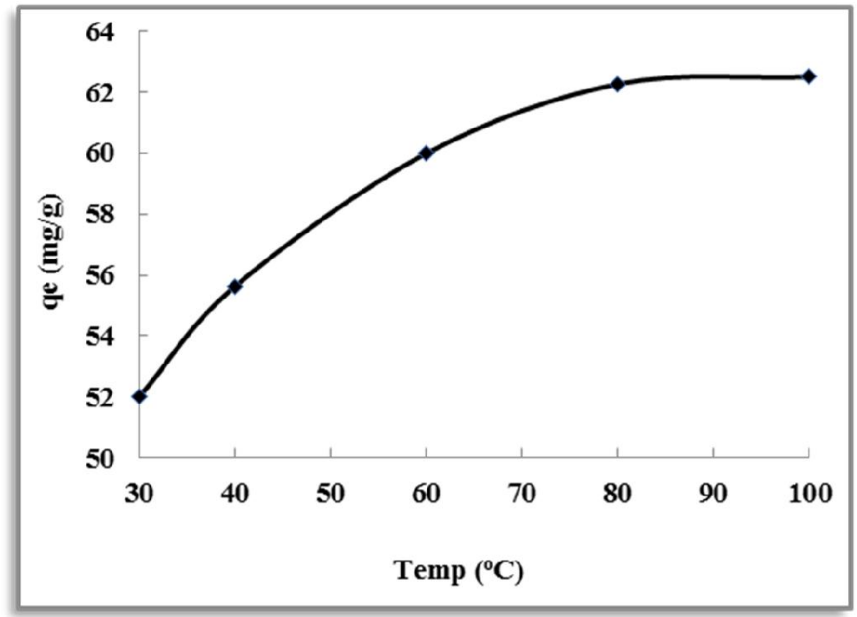

Fig. 11: Effect of temperature on $\mathrm{Cr}$ biosorption process onto A. niger dried biomass 


\section{Desorption and regeneration}

\section{Desorption of loaded metals}

The different tested desorbing agents revealed that $\mathrm{Na}_{2} \mathrm{CO}_{3}(1 \mathrm{M})$ is the most efficient one where it gave desorption percent for $\mathrm{Cr}$ reached $76 \%$ (Table 4). On the other hand, testing of various $\mathrm{Na}_{2} \mathrm{CO}_{3}$-concentrations illustrated that $1 \mathrm{M}$ is the optimum concentrations giving desorption efficiencies $76 \%$ for $\mathrm{Cr}$ (Table 5).

Table 4: Effect of the different eluting agents on desorption of $\mathrm{Cr}$ from A. niger dried biomass.

\begin{tabular}{cc}
\hline Eluting agents(1M) & Metal desorption $\mathbf{C r} \%$ \\
\hline $\mathbf{H}_{2} \mathbf{S O}_{4}$ & 75.7 \\
$\mathbf{H C l}$ & 75.13 \\
$\mathrm{Na}_{2} \mathbf{C O}_{3}$ & 76.00 \\
$\mathbf{H N O}_{3}$ & 75.80 \\
\hline
\end{tabular}

Table 5: Effect of different concentrations of $\mathrm{Na}_{2} \mathrm{CO}_{3}$ on desorption of $\mathrm{Cr}$ from A. niger dried biomass.

\begin{tabular}{cc} 
Different concentrations of $\mathrm{Na}_{2} \mathrm{CO}_{3}(\mathrm{M})$ & Cr Metal desorption \% \\
0.5 & 75.35 \\
1 & 76 \\
1.5 & 75 \\
2 & 75 \\
\hline
\end{tabular}

\section{Biomass reusability}

The successive adsorption/desorption cycles indicated that the dried A. niger behaves as an effective bio-sorbent for the $4^{\text {th }}$ cycle for Cr removal (Table 6). Such results encourage using of the dried $A$. niger to reduce the capital cost accompanying efficient pollutants removal from the liquid wastes.

Table 6: Effect of multiple sorption/desorption cycles on the uptake efficiency

\begin{tabular}{cccccc}
\hline \multirow{2}{*}{ Metals- uptake (mg/g) } & \multicolumn{5}{c}{ Sorption/desorption cycles } \\
& $1^{\text {st }}$ & $2^{\text {nd }}$ & $3^{\text {rd }}$ & $4^{\text {th }}$ & $5^{\text {th }}$ \\
\hline $\mathrm{Cr}$ & 52 & 48 & 34 & 22 & 15 \\
\hline
\end{tabular}

\section{Application on the real liquid waste}

As a consequence of the batch experiments, the conducted optimum adsorption conditions were applied on the real liquid waste. Comparing the results of the chemical analysis of the liquid waste before and after treatment with the dried biomass (Table 7) revealed the efficient adsorption role played by the $A$. niger on $\mathrm{Cr}$ as well as other metals such as; $\mathrm{U}, \mathrm{Th}, \mathrm{Fe}, \mathrm{Cr}, \mathrm{Cu}, \mathrm{Zn}, \mathrm{Mo}, \mathrm{As}, \mathrm{Pb}, \mathrm{V}$ and REEs. It is worth to notice that the bio-uptake for elements are lesser values than those obtained from the batch experiments, but such behavior seems reasonable when we consider the competence of the other included ions species in the liquid waste on the binding sites of the bio-adsorbent. However, the results support using A. niger as a qualified adsorbent for the treatment of the liquid wastes that could be originated from various activities.

\section{The biomass changes accompanied the adsorption process}

Verifying changes of the biomass surface and functional groups due to $\mathrm{Cr}$ adsorption was attained by exposing the dried biomass (before and after adsorption process) for investigation using the environmental scanning electron microscope-energy dispersive X-ray (ESEM-EDX) and the Fourier transform infrared spectroscopy (FTIR). 
Table 7: The chemical analysis of the liquid waste before and after treatment by $A$. niger dried biomass (n.d. $=$ not detected).

\begin{tabular}{|c|c|c|}
\hline \multirow[t]{2}{*}{ Element } & \multicolumn{2}{|c|}{ Concentration (ppm) } \\
\hline & Before & After \\
\hline $\mathbf{F e}$ & 01.59 & n.d \\
\hline $\mathrm{Cr}$ & 55.23 & 01.62 \\
\hline Co & n.d. & n.d. \\
\hline $\mathbf{C u}$ & 00.07 & n.d. \\
\hline $\mathbf{N i}$ & n.d. & n.d. \\
\hline $\mathbf{Z n}$ & 00.48 & n.d. \\
\hline Mo & 00.17 & 00.05 \\
\hline Cd & n.d. & n.d. \\
\hline B & 00.15 & n.d \\
\hline $\mathbf{B a}$ & n.d. & n.d. \\
\hline As & 00.23 & 00.02 \\
\hline $\mathbf{P b}$ & 00.19 & n.d. \\
\hline $\mathbf{V}$ & 00.48 & 00.44 \\
\hline REES & 01.11 & n.d. \\
\hline
\end{tabular}

\section{ESEM-EDX investigation}

Changing of $A$. niger surface shape before and after sorption of $\mathrm{Cr}$ and the elemental analysis of the loaded ions were investigated by the ESEM-EDX (Figs. 12-13). Both criteria verified the success sorption process by the used biomass where the morphological changes are attributed to the sorption Cr on the binding sites of the biomass.

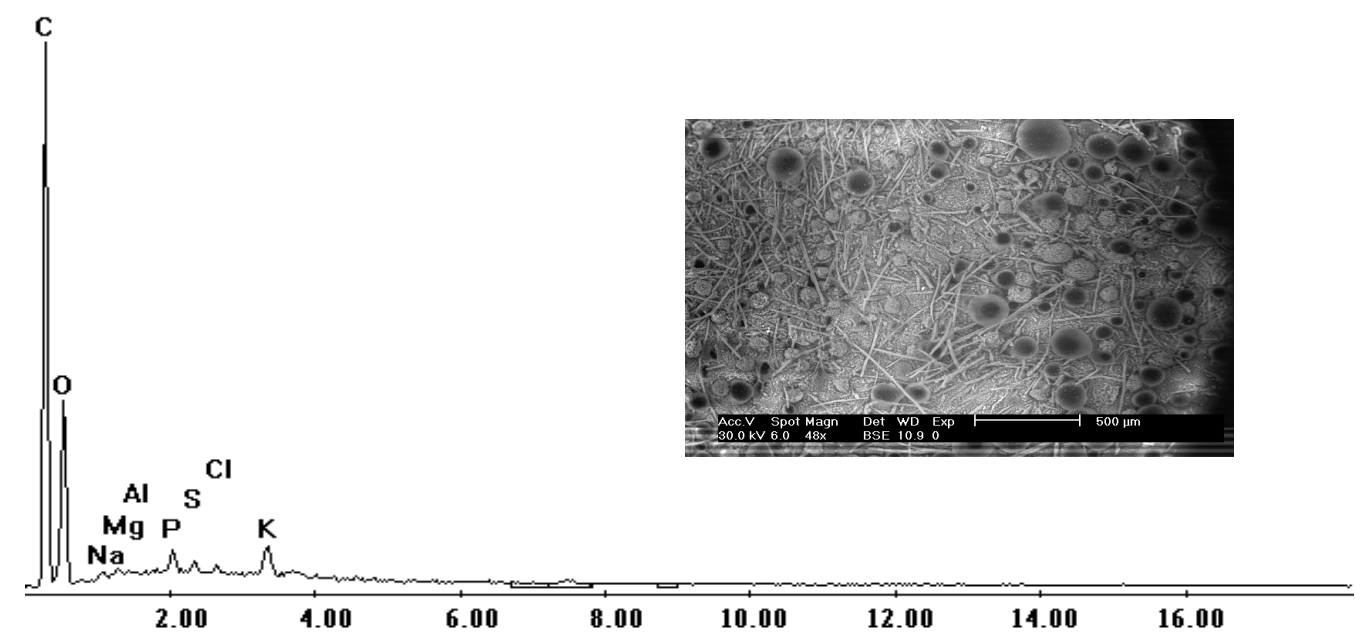

Fig. 12: ESEM-EDX chart showing the surface shape of the A.niger before the adsorption process were no signs for bonded metals 


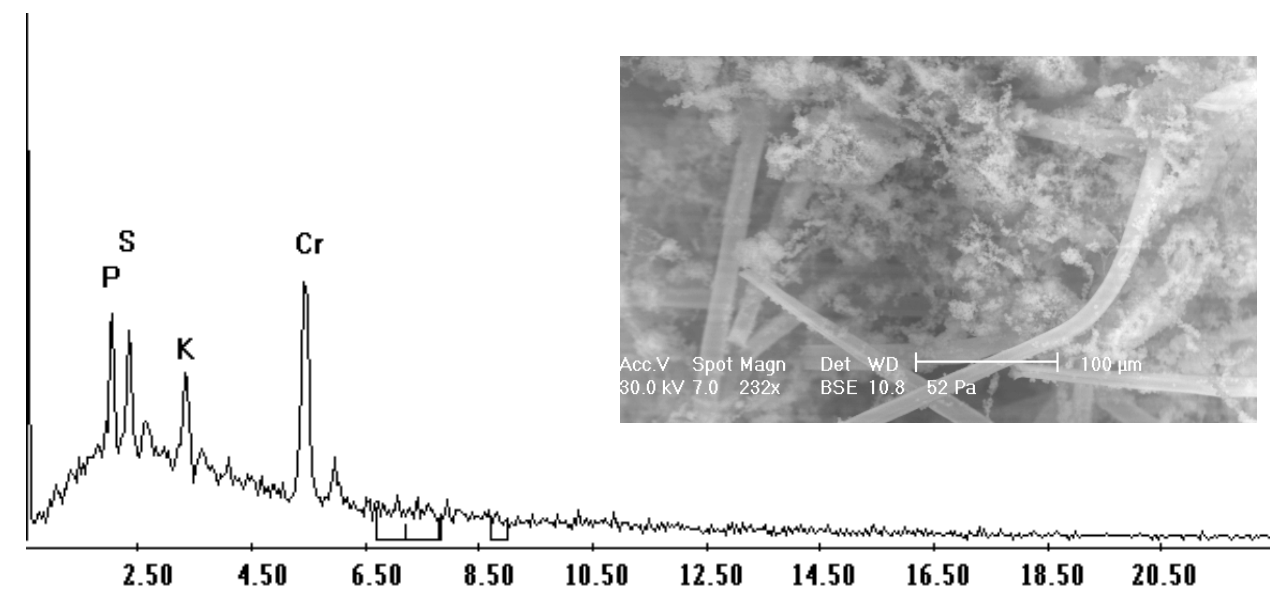

Fig. 13: ESEM-EDX chart showing changes of $A$. niger surface morphology due to adsorption of $\mathrm{Cr}$ ions

\section{FTIR investigation}

The FTIR spectra illustrated the positions and intensities of the functional group's peaks before and after the sorption processes (Table $8 \&$ Figs. 14). The noticed shifting of the peak-bands before and after sorption of Cr onto the A. niger is a strong indication for the functional group's participation in the interaction of the ion on the immobilized fungal beads. Moreover, this shifting can be attributed to the surface complication created between metals and the carboxylic functional groups which probably support the chemical complication as one of the available mechanisms drives the biosorption process of Cr.

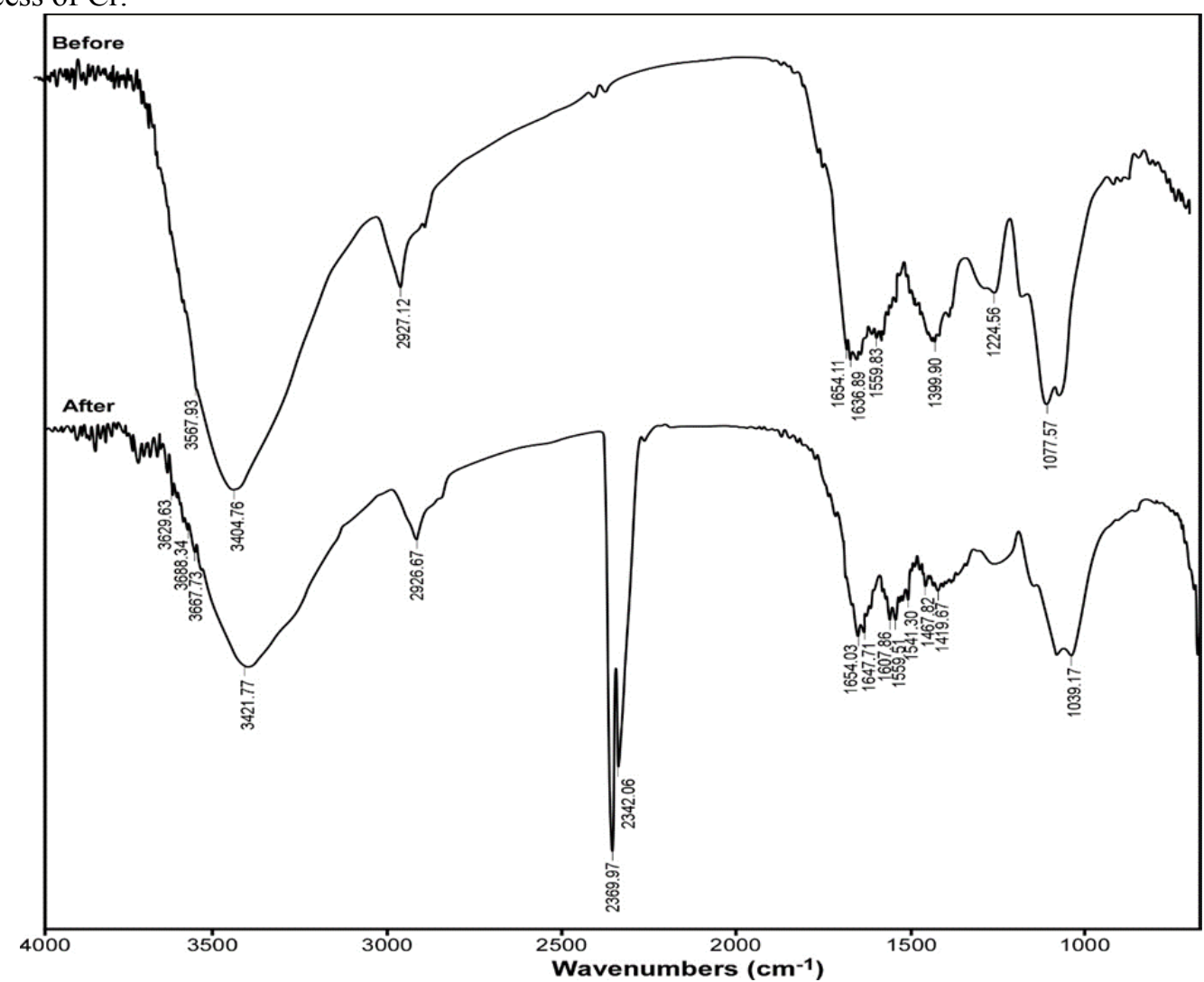

Fig. 14: The FTIR spectra of the unloaded $A$. niger 
Table 8: The functional groups and their wavelengths before and after sorption of $\mathrm{Cr}$

\begin{tabular}{lll}
\hline Functional group & Before sorption & After Cr-sorption \\
\hline O H & 3567.93 & 3629.63 \\
C H & 2927.1 & 2927.12 \\
C= O & 1654.11 & 1654.03 \\
\hline
\end{tabular}

\section{Environmental protection and metal recovery}

The adsorbed $\mathrm{Cr}$ by $A$. niger dried biomass was recovered in ash forms. The recovered $\mathrm{Cr}$ was in the form of green-colored precipitation product (fig. 15).

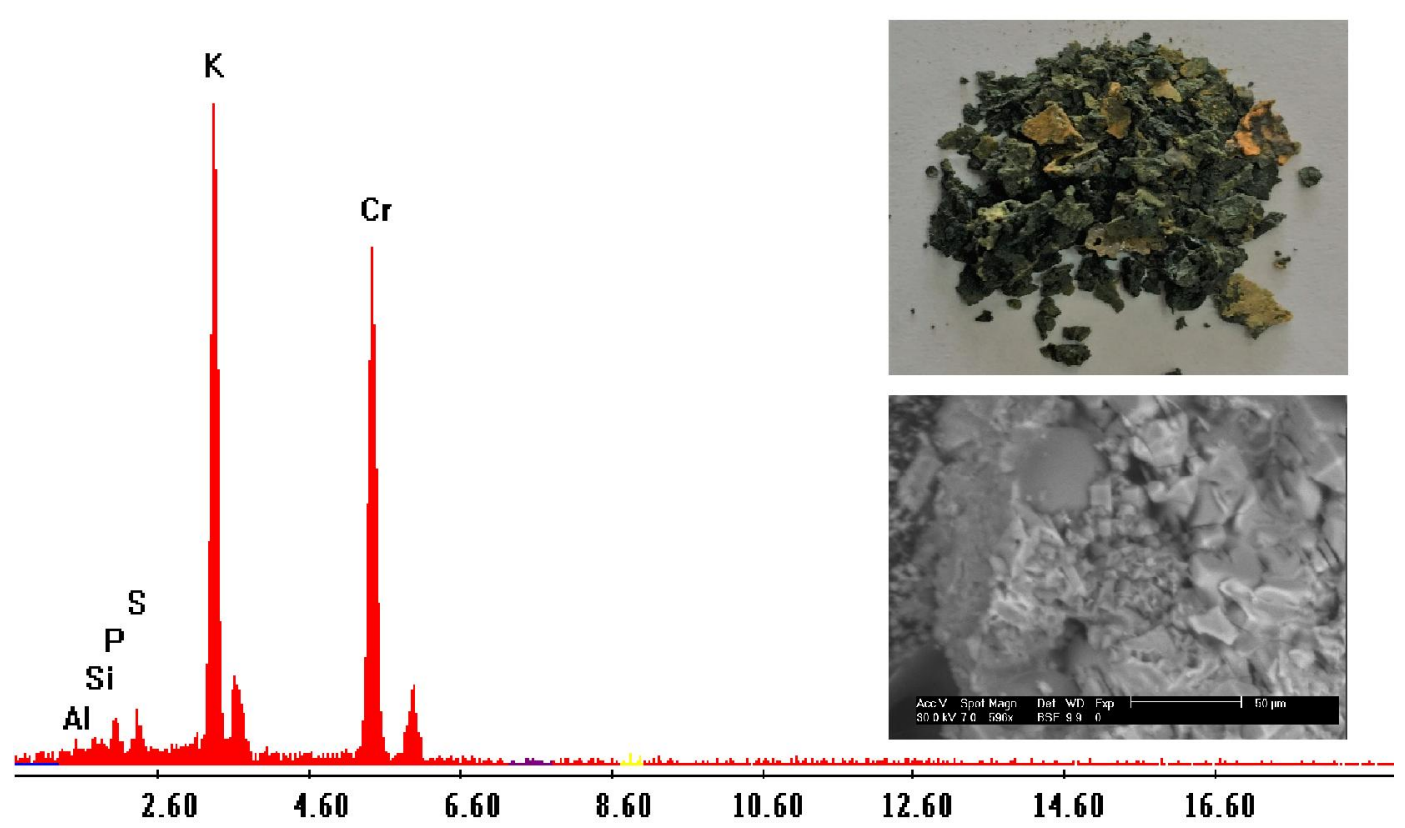

Fig. 15: Recovered chromium and its ESEM-EDX chart

\section{References}

Abd El-Magied, M.O., A.M. Hassan, H.M.H. Gad, T.F. Mohammaden, M.A.M. Youssef, 2017a. Removal of nickel (II) ions from aqueous solutions using modified activated carbon: A kinetic and equilibrium study, J. Dispersion Sci. Technol., 39:862-873.

Abd El-Magied, M.O., A. Mansour, F.A. Alsayed, M.S. Atrees and S. Abd Eldayem, 2018a Biosorption of beryllium from aqueous solutions onto modified chitosan resin: equilibrium, kinetic and thermodynamic study, J. Dispersion Sci. Technol., 39:597-1605.

Abd El-Magied, M.O., T.F. Mohammaden, I.K. El-Aassy, H.M.H. Gad, A.M. Hassan and M.A.Mahmoud, 2017b. Decontamination of uranium-polluted groundwater by chemicallyenhanced, sawdust-activated carbon, Colloids Interfaces 1:1-17.

Abd El-Magied, M.O., W.M. Salem, A.A. Daher and A. Elshehy, 2018b. Fabrication of silica microspheres(HB/A@SI-MNS) for hafnium and zirconium recovery from zirconyl leach liquor, Colloids Interfaces, 2:1-14

Abdullah, N., N. Yusof, W.J. Lau, J. Jaafar and A.F. Ismail, 2019. Recent trends of heavy metal removal from water/wastewater by membrane technologies. Journal of Industrial and Engineering Chemistry, 76, (25):17-38.

Abu El-Soad, A.M., M.O. Abd El-Magied, E.G. Kovaleva and G. Lazzara, 2019. Synthesis and characterization of modified sulfonated chitosan for beryllium recovery. International journal of biological macromolecules, 139:153-160 
Ahmad, I., M.I. Ansari and F. Aqil, 2006. Biosorption of Ni, Cr and Cd by metal tolerant Aspergillus niger and Penicillium sp. using single and multi-metal solution. Indian J. of Experimental Biology, 44(1): 73-76.

Alluri, H.K., S.R. Ronda, V.S. Settalluri, J.S. Bondili, V. Suryanarayana, P. Venkateshwar, 2007. Biosorption: An eco-friendly alternative for heavy metal removal. African Journal of Biotechnology, 6 (25):2924-2931.

Altschul, S.F., T.L. Madden, A.A. Schaffer, J.H. Zhang, Z. Zhang, W. Miller and D.J. Lipman, 1997. Gapped BLAST and PSI-BLAST: a new generation of protein database search programs. Nucleic Acids Research, 25:3389-3402.

Barnett, H.L. and B.B. Hunter, 1999. Illustrated genera of imperfect fungi, fourth edition. Prentice Hall Inc.

Brady, D. and J.R. Duncan, 1994. Bioaccumulation of metal-cations by Saccharomyces cerevisiae. Appl Microbiol Biotechnol., 41:149-54.

Celik, A., and A. Demirbas, 2005. "Removal of heavy metal ions from aqueous solutions via adsorption onto modified lignin from pulping wastes." Energy Sources, 27(12), 1167-1177.

Domsch, K. H., W. Gams, and T.H. Anderson, 1980. Compendium of soil fungi. London, England: Acadamic Press.

Donia, A.M., Atia, A.A., Moussa, E.M.M., El-Sherif, A.M., Abd El-Magied, M.O. (2009). Removal of Uranium (VI) from aqueous solutions using glycidyl methacrylate chelating adsorbents. Hydrometallurgy 95:183-189.

Doshi, H., A. Ray and I. L. Kothari, 2007. Bioremediation potential of live and dead Spirulina: spectroscopic, kinetics and SEM studies." Biotechnology and Bioengineering, 96(6):10511063.

Esposito, A., F. Pagnanelli and F. Veglio, 2002. pH-related equilibria models for biosorption in single metal systems. ChemEng Sci., 57:307-13.

Faisal, M., and S. Hasnain, 2004. "Comparative study of $\mathrm{Cr}(\mathrm{VI})$ uptake and reduction in industrial effluent by Ochrobactrum intermedium and Brevibacteriumsp. Biotechnology Letters, 26(21): $1623-1628$

Ferraz, A.I., T. Tavares and J.A. Teixeira, 2004. Cr(III) removal and recovery from Saccharomyces cerevisiae. Chem Eng J., 105:11-20.

Freundlic., H.M.F., 1906. Uber die adsorption in losungen, Zeitschrift fur Physikalische Chemie (Leipzig) 57:385-470.

Glasston, S., K.J. Laidler and H. Eyring, 1941. The Theory of Rate Processes: the kinetics of chemical reactions, viscosity, diffusion and electrochemical phenomena, McGraw-Hill, New York.

Gokila, S., T. Gomathi, P. Sudha and S. Anil, 2017. Removal of the heavy metal ion chromiuim (VI) usingChitosan and Alginate nanocomposites. International journal of biological macromolecules, 104: 1459-1468.

Hlihor, R.M., H. Figueiredo, T. Tavares and M. Gavrilescu, 2017. Biosorption potential of dead and living Arthrobacter viscosus biomass in the removal of $\mathrm{Cr}(\mathrm{VI})$, batch and column studies. Process Safetyand Environmental Protection, 108, 44-56. 866.

Iyer, A., K. Mody and B. Jha, 2005. Biosorption of heavy metals by a marine bacterium. Marine Pollution Bulletin, 50, 340-343.

Kapoor, A. and T. Viraraghavan, 1995. Fungi biosorption an alternative treatment option for heavy metal bearing wastewaters: a review. Bioresour Technol., 53:195-206

Kratochvil, D., P. Pimentel and B. Volesky, 1998. Removal of trivalent and hexavalentchromium by seaweed biosorbent. Environ Sci Technol., 32: 2693-8.

Langmuir, I., 1918. The adsorption of gases on plane surfaces of glass, mica and platinum, J. Am. Chem. Soc., 40:1361-1367.

Lee, Y.H., P.J. Adams and D.T. Shindell, 2015. Evaluation of the global aerosol microphysical Model E2-TOMAS model against satellite and ground-based Geosci. Model Dev., 8: 631-667.

Malik, A., 2004. Metal bioremediation through growing cells. Environ Int., 30:261-78.

Mane, P.C., A.B. Bhosle and C.M. Jangam, 2011. "Effect of Pretreatment of Algal Biomass on Bioadsorption of Chromium from Aqueous Solution. Research Journal of Chemistry and Environment, 15(2): 271-274. 
Munoz, A.J., E. Ruiz, H. Abriouel, A. Galvez, L. Ezzouhri, K. Lairini and F. Espinola, 2012. "Heavy metal tolerance of microorganisms isolated from wastewaters: Identification and evaluation of its potential for biosorption." Chemical Engineering Journal, 210, 325-332.

Oves, M., M.S. Khan and H.A.bQari, 2017. Ensiferadhaerens for heavy metal bioaccumulation, biosorption, and phosphate solubilization under metal stress condition. Journal of the Taiwan Institute of Chemical Engineers, 1-13.

Özer, A., and D. Özer, 2003. Comparative study of the biosorption of $\mathrm{Pb}(\mathrm{II}), \mathrm{Ni}(\mathrm{II})$ and $\mathrm{Cr}(\mathrm{VI})$ ions onto S. cerevisiae: determination of biosorption heats. J Hazard Mater B., 100:219-29.

Pehlivan, E. and T. Altun, 2008. Biosorption of chromium(VI) ion from aqueous solutions using walnut, hazelnut and almond shell. Journal of Hazardous Materials 155(1-2):378-84 ·

Porter, J., D. Deere, R. Pickup and C. Edwards, 1996. Fluorescent probes and flow cytometry: new insights into environmental bacteriology. Cytometry, 23:91-96.

Reddad, Z., C. Gerente, Y. Andres and P. Cloirec, 2002. Adsorption of several metal ions onto a lowcost biosorbents: Kinetics and equilibrium studies. Environ Sci Technol., 36: 2067-2073.

Sadeek, A. S., M.A. El-Sayed, M.A. Amine and M.O.Abd El- Magied, 2014. Selective solid-phase extraction of U(VI) by amine functionalized glycidyl methacrylate, J Environ Chem Eng., 2:293-303.

Sar, P and S.F. D'Souza, 2002. Biosorption of thorium (IV) by a Pseudomonas biomass Nuclear Agriculture and Biotechnology Division, Bhabha Atomic Research Centre, Trombay, Mumbai 400 085, India Biotechnology Letters, 24: 239-243.

Talaiekhozani, A. and S. Rezania, 2017. Application of photosynthetic bacteria for removal of heavy metals, macro-pollutants and dye from waste water: A review. Journal of Water Process Engineering, 19:312-321.

Tunali, S., Cabuk, A. and T.Akar, 2006. Removal of lead and copper ions from aqueous solutions by bacterial strain isolated from soil. Chemical Engineering Journal, 115(3):203-211.

Veglio, F. and F. Beolchini, 1997. Removal of metals by biosorption: a review. Hydrometallurgy, 44:301-16.

Volesky B., 1994. Advances in biosorption of metals-selection of biomass types. Fems Microbiol Rev., 14:291-302.

Wang, J.L., 2002. Immobilization techniques for biocatalysts and waterpollution control. Beijing: Science Press; a [in Chinese].

Wang, J. and C. Chen, 2014. Chitosan-based biosorbents: Modification and application forbiosorption of heavy metals and radionuclides Bioresource Technology, 160:129-141

Wang, T., X. Zheng, X. Wang, X. Lu and Y. Shen, 2017. Different biosorption mechanisms of Uranium (VI) by live and heat-killed Saccharomyces cerevisiae under environmentally relevant conditions. Journal of Environmental Radioactivity 167: 92-99.

Yi, Z. and B. Lian, 2012. Adsorption of U(VI) by Bacillus mucilaginous. J Radioanal. Nucl. Chem. 293:321-329.

Yun, Y. S., D. Park, J.M. Park and B. Volesky, 2001. Biosorption of trivalent chromium on the brown seaweed biomass. Environ Sci Technol., 35: 4353-4358.

Zafar, S., F. Aqil and I. Ahmad, 2006. Metal tolerance and biosorption potential of filamentous fungi isolated from metal contaminated agricultural soil. Bioresour Technol., 98, 2557-2561. 